\title{
Albert in Leonida Mrgole: \\ IZŠTEKANI NAJSTNIKI IN STARŠI, KI ŠTEKAJO
}

\author{
Kamnik, zavod Vezal, 2013
}

Priročnik Izštekani najstniki in starši, ki štekajo je že po naslovu nekoliko poseben, saj uporablja slengovske besede, katerih pomen pa takoj razumemo. Avtorja v uvodu in tudi na spletni strani (http://najstniki.weebly.com/) pojasnita, da je naslov takšen, ker se je »prijel« in nagovoril potencialne bralce. To je tudi namen priročnika, da se približa bralcu in bralki in jima sporoči (spo)znanja, ki izhajajo iz osebnih izkušenj avtorja in avtorice, ki sta starša štirih otrok. Spoznanja izhajajo tudi iz njunih raznolikih izobraževalnih, svetovalnih in terapevtskih izkušenj z delom s starši in mladostniki ter iz strokovne in znanstvene literature. Starši bodo v priročniku našli odgovore na vprašanja, kako ravnati v konkretnih situacijah. Priročnik je doživel zelo dober sprejem, pripravlja se druga dopolnjena izdaja in prevod $\mathrm{v}$ angleški jezik, ki bo iž̌el prihodnje leto.

Slog pisanja je prepričljiv in humoren. Že v zahvali svojim otrokom avtorja napišeta, da jima je bil vedno omogočen »popravni izpit«, kadar »sta ga polomila«, in da sta kot starša vedno dobila nove priložnosti. Avtorja sporočata, da se starši nenehno učijo, da ozaveščajo svoje delovanje in ga refleksivno spreminjajo, zato je vsebina za starše izzivalna tudi (ali še posebej) v trenutkih, ko so ob svojem najstniku nemočni in bi ga najraje »vrgli iz hiše «. O vsakdanjih odnosih z najstniki pišeta s pomočjo zgodb, konkretnih primerov. Zgodbe z zapleti in razpleti celovito predstavijo pojav/problem in pripovedujejo, da so še tako zapleteni problemi rešljivi. V knjigi je zbranih veliko resničnih zgodb, ki so temelj za prenašanje spoznanj in spodbujanje osebne refleksije, zato je branje kratkočasno. V ozadju nasvetov in zgodb pa so teoretska podlaga emocionalno usmerjene terapije (Emotionally Focused Therapy), teorija navezanosti (Bowlby), sodobne ugotovitve nevroznanosti (Siegel), koncept čuječnosti (mindfulness) ali ozaveščenih staršev, kot to imenujeta avtorja. Zasledimo lahko vpliv narativnih pristopov, teorije izbire (Glasser) in imago terapije.

Že naslov nam daje slutiti, da bo temeljna tema povezanost (štekanje) in medsebojno razumevanje ter delovanje. Imeti stik z otroki je najboljše izhodišče za vzgojo. »Izštekani najstniki« so mladostniki, ki se v puberteti in adolescenci odmaknejo iz odnosov v iskanju svoje lastne identitete in samostojnosti. V tem odmaknjenem času mnogokrat presenetijo svoje starše z izrazi, reakcijami, odločitvami, obleko, nakitom ... Avtorja predstavita starše kot ključne akterje, nosilce družinskega sistema, od katerih so odvisni razpleti zgodb. Če se starši zavedajo, kako pomembno je oblikovati varno navezanost za razvoj otroka, bodo s svojim ravnanjem in odločitvami to počeli že od otrokovega rojstva dalje (in ne šele v puberteti). Ker pa se vloge staršev ljudje učijo v odnosih 
s svojimi starši, je treba razmisliti tudi o tem, kakšne spomine (prepričanja, navade) prinašajo iz svojih primarnih družin. Uzavestiti morajo svoje izkušnje in na tej podlagi graditi refleksivno starševstvo. Starši, ki v svojih družinah niso imeli izkušnje varne navezanosti, imajo lahko veliko težav.

V drugem delu knjige so zbrani primeri o potrebah najstnikov (gre za 22 tem, npr. stik, meje, pravila, odgovornost, moč, komunikacija, zabava, ljubezen ...), ki imajo zanimivo strukturo. Na začetku je zgoščen strokovni opis, npr. pripadnost in bližina, temu sledi pripoved, npr. zgodba o boju za moč v družini. Nato dobijo starši okvir za premislek (V okviru zavedanja). Ko starši preobrazijo svoje poglede, kar bi lahko interpretirali kot transformativno učenje v vlogi starša, oblikujejo tudi nove odzive, nove odgovore. Vsaka tema se sklene z razdelkom Namigi in preverjene rešitve.

Tretji del priročnika prinaša zgodbe, ki so se zapletle in jih starši (junaki zgodb) ne bi želeli več doživeti (težave s šolo, depresija, zasvojenost, laži, samopoškodbe, nasilje, nezaščitena spolnost ...). Čeprav so opisane izkušnje zelo kompleksne in včasih na meji obupa, ohranjata avtorja v podtonu optimizem, ki sporoča, da je povsod upanje in da so še tako zapletene situacije rešljive. V sklepnem delu (Epilog) so delavnice za osebno delo (Razumevanje lastnih nedokončanih zgodb, Dve možnosti pogleda na najstnike, Znaki zlorabljanja opojnih substanc). Tako avtorja z vprašanji vodita bralčevo avtorefleksijo o lastnih izkušnjah in prepričanjih.

Knjiga je dragocena, ker je nastala v slovenskem okolju in zrcali dogajanje v naši kulturi, česar ne more storiti nobena prevedena literatura, vsaj ne enako specifično. Zato bo dobrodošla tako za starše kot tudi za profesionalne vzgojitelje in učitelje. Drugič pa je dragocena zato, ker je »družinsko delo«. Opremljena je namreč z ilustracijami Izaka Mrgoleta, sina avtorjev, izšla pa je pri zavodu Vezal (http://www.vezal.si/), ki ga vodita avtorja priročnika. Priročnik je napisan z željo, da bi bilo ljudem v družinah lepše, da bi nase in na svoje otroke znali pogledati z nove perspektive.

Nives Ličen 